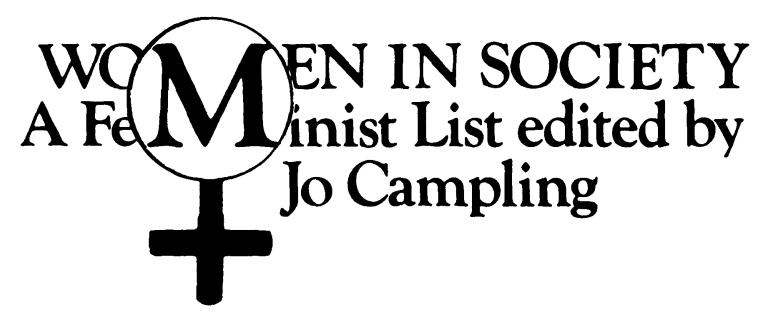

Published

Sheila Allen and Carol Wolkowitz Homeworking: myths and realities

Niamh Baker Happily Ever After? Women's fiction in postwar Britain, 1945-60

Jenny Beale Women in Ireland: voices of change

Jennifer Breen In Her Own Write: twentieth-century women's fiction

Ruth Carter and Gill Kirkup Women in Engineering

Angela Coyle and Jane Skinner (editors) Women and Work: positive action for change

Gillian Dalley Ideologies of Caring: rethinking community and collectivism

Leonore Davidoff and Belinda Westover (editors) Our Work, Our Lives, Our

Words: women's history and women's work

Emily Driver and Audrey Droisen (editors) Child Sexual Abuse: feminist perspectives

Lesley Ferris Acting Women: images of women in theatre

Diana Gittins The Family in Question: changing households and familiar ideologies

Tuula Gordon Feminist Mothers

Eileen Green, Sandra Hebron and Diana Woodward Women's Leisure, What

Leisure?

Frances Heidensohn Women and Crime

Ursula King Women and Spirituality: voices of protest and promise

Muthoni Likimani (Introductory Essay by Jean O'Barr) Passbook Number F.47927: women and Mau Mau in Kenya

Jo Little, Linda Peake and Pat Richardson (editors) Women in Cities: gender and the urban environment

Susan Lonsdale Women and Disability: the experience of physical disability among women

Sharon Macdonald, Pat Holden and Shirley Ardener (editors) Images of Women in Peace and War: cross-cultural and historical perspectives

Mavis Maclean Surviving Divorce: women's resources after separation

Shelley Pennington and Belinda Westover A Hidden Workforce: homeworkers in England, 1850-1985

Vicky Randall Women and Politics: an international perspective (2nd edn)

Rosemary Ridd and Helen Callaway (editors) Caught Up in Conflict: women's responses to political strife

Patricia Spallone Beyond Conception: the new politics of reproduction

Taking Liberties Collective Learning the Hard Way: women's oppression in men's education

Clare Ungerson (editor) Women and Social Policy: a reader

Kitty Warnock Land before Honour: Palestinian women in the Occupied

Territories

Annie Woodhouse Fantastic Women: sex, gender and transvestism 


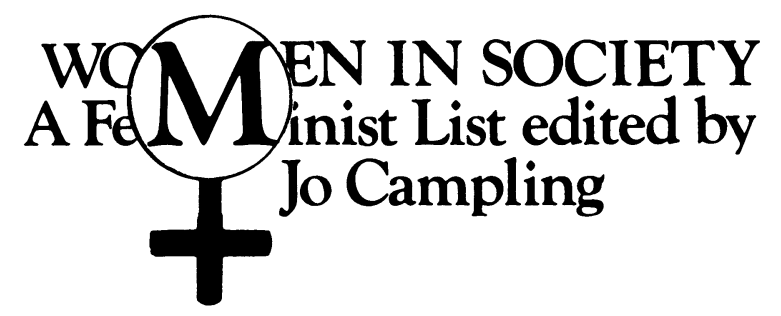

editorial advisory group

Maria Brenton, University College, Cardiff; Phillida Bunckle, Victoria University, Wellington, New Zealand; Miriam David, Polytechnic of the South Bank; Leonore Davidoff, University of Essex; Janet Finch, University of Lancaster; Jalna Hanmer, University of Bradford; Beverley Kingston, University of New South Wales, Australia; Hilary Land, Royal Holloway and Bedford New College, University of London; Diana Leonard, University of London Institute of Education; Susan Lonsdale, Polytechnic of the South Bank; Jean O'Barr, Duke University, North Carolina, USA; Arlene Tigar McLaren, Simon Fraser University, British Columbia, Canada; Jill Roe, Macquarie University, Australia; Hilary Rose, University of Bradford; Susan Sellers, Centre D'Etudes Féminines, Université de Paris, France; Pat Thane, Goldsmiths' College, University of London; Clare Ungerson, University of Kent at Canterbury; Judy Walkowitz, Rutgers University, New Jersey, USA.

The 1970s and 1980s have seen an explosion of publishing by, about and for women. This new list is designed to make a particular contribution to this process by commissioning and publishing books which consolidate and advance feminist research and debate in key areas in a form suitable for students, academics and researchers but also accessible to a broader general readership.

As far as possible books will adopt an international perspective incorporating comparative material from a range of countries where this is illuminating. Above all they will be interdisciplinary, aiming to put women's studies and feminist discussion firmly on the agenda in subject-areas as disparate as law, physical education, art and social policy.

A list of published titles follows overleaf 


\section{Surviving Divorce}

\section{Women's Resources after Separation}

\section{Mavis Maclean}

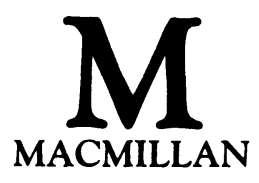




\section{(C) Mavis Maclean 1991}

All rights reserved. No reproduction, copy or transmission of this publication may be made without written permission.

No paragraph of this publication may be reproduced, copied or transmitted save with written permission or in accordance with the provisions of the Copyright, Designs and Patents Act 1988 , or under the terms of any licence permitting limited copying issued by the Copyright Licensing Agency, 33-4 Alfred Place, London WC1E 7DP.

Any person who does any unauthorised act in relation to this publication may be liable to criminal prosecution and civil claims for damages.

First published 1991

Published by MACMILLAN EDUCATION LTD

Houndmills, Basingstoke, Hampshire RG21 2XS and London

Companies and representatives

throughout the world

Photoset in Times by

Vine \& Gorfin Ltd, Exmouth, Devon

British Library Cataloguing in Publication Data

Maclean, Mavis

Surviving divorce: women's resources after separation.

(Women in society).

1. Divorce. Personal adjustment of women

I. Title II. Series

306.89

ISBN 978-0-333-46534-9 ISBN 978-1-349-21341-2 (eBook)

DOI 10.1007/978-1-349-21341-2

\section{Women in Society series}

\section{Series Standing Order}

If you would like to receive future titles in this series as they are published, you can make use of our standing order facility. To place a standing order please contact your bookseller or, in case of difficulty, write to us at the address below with your name and address and the name of the series. Please state with which title you wish to begin your standing order. (If you live outside the United Kingdom we may not have the rights for your area, in which case we will forward your order to the publisher concerned.) 
For Sarah and Caroline 


\section{Contents}

Acknowledgements

viii

Introduction: women and their money after divorce

\section{PART I OVERVIEW}

1. Family change and economic tensions: the role of law

2. Negotiating an income: women as economic actors

3. Employment: the way forward?

\section{PART II STRATEGIES FOR SURVIVAL}

4. Remarriage: the American example

5. Welfare accounting: the UK experience

6. Employers' attitudes

7. Family policy: work, welfare and family life - the French partnership

8. Ways and means

Bibliography

Index 


\section{Acknowledgements}

Women heads of households have a hard time.

I have discussed some of the ways and means by which they put together an income in different countries, hoping to stimulate thinking about how to develop a comprehensive collective response.

I am greatly indebted to my colleagues John Eekelaar in Oxford, Laura Voneche in Geneva, Benoit Bastard in Paris for their collaboration; and to Lenore Weitzman, Greg Duncan and Martin Rein in the United States.

MAVIS MACLEAN 